Magical Urbanism: Walter Benjamin and Utopian Realism in the film Ratcatcher Alex Law \& Jan Law

University of Abertay Dundee/University of Strathclyde

Paper for Historical Materialism's Special Issue on the Fantastic

Revised 2 July 2002 


\section{Magical Urbanism: Walter Benjamin and Utopian Realism in the film Ratcatcher}

Walter Benjamin today enters through academic portals under a 'Welcome' sign. ${ }^{1}$ In crossing this threshold Benjamin is turned outside-in through a series of reversals. Rejected in his own lifetime by an anti-Semitic university establishment and confronted with a calamitous political situation the living Benjamin was denied the insider status of institutional respectability. Instead he was banished to the outside where, as Esther Leslie puts it, 'Benjamin had little choice but to jostle in the streets and in the marketplace'. ${ }^{2}$ Surviving successive intellectual fashions for Critical Theory, structuralism and, latterly, post-structuralism no other revolutionary thinker is now feted by homo academicus as much as Benjamin. Unfortunately the condition of this acceptance has often been to overpower Benjamin's revolutionary temper and stubborn materialism. A barely concealed nihilistic relativism focuses on the 'poetics' and infinite allusions of a new, post-modern Benjamin. In this way Benjamin is made amenable to the very scholastic conformism that he himself lambasted as 'a tool of the ruling classes' ${ }^{3}$ By safely filing Benjamin away as a cultural guru of peerless genius embarrassment at the reductive materialism of his 'modernist' valorisation of technology might be avoided. Benjamin's materialist attitude to the technical forces of production was long thought to be out of date, its 'productivism' displaced, first, by the barbarism of Auschwitz and, later, by a fully recuperative, 'hyper-realist' culture industry. ${ }^{4}$ Benjamin opposed such cultural and political despair without succumbing to facile optimism about the emancipatory power of 'culture', popular or otherwise.

\footnotetext{
${ }^{1}$ We would like to acknowledge the critical referee's comments in the development of our argument. Thanks also to participants at the Screen Studies conference, Glasgow, June 2002. ${ }^{2}$ Leslie 2000, p. 218.

${ }^{3}$ Benjamin 1973a, p. 247; Leslie 2000.
} 
Instead, Benjamin argued that an improved technical apparatus of cultural production might turn passive audiences into active collaborators by bringing them into contact with the cultural production process itself. The argument here is that by setting Benjamin squarely within a Marxist approach to utopics and a cultural technology like cinema something of the subversive surplus of the fantastic can be divined. To this end, this paper brings the film Ratcatcher into alignment with Benjamin's insights to demonstrate the continuing relevance of film's technical and political potential to alter perception and stamp an impression on consciousness. ${ }^{5}$

\section{Urban shocks and filmic 'innervation'}

\section{Allegory and Dialectical Images}

Allegory provided Benjamin with a materialist theory of avant-garde modernism. ${ }^{6}$ Modernist allegory smashes-up the illusion of the organic whole of classic romanticism and realism to de-naturalise its isolated fragments. History becomes frozen in an image of decay, of ruins, of wreckage. Set adrift from its original function within an organic whole, new meaning is re-constructed out of the petrified fragments. But the expense of this loss of original coherence is to render meaning opaque, borderline, almost incomprehensible. Incapable of resurrecting the original totality, allegory becomes 'melancholic'. ${ }^{7}$ The solitary proximity of melancholia to death opens-up thing-like objects, normally so inscrutable, to micrological inspection and study. From the standpoint of a jaded intellectual elite, the kind that gather today around postmodern verities, melancholia assumes a stereotypical 'hollow form': 'A know-all irony thinks it has much more in these supposed stereotypes than in the

\footnotetext{
${ }^{4}$ Adorno 1977; Jameson 1977.

${ }^{5}$ Bratu Hansen 1999.

${ }^{6}$ Burger 1984.

${ }^{7}$ Pensky 1993.
} 
things themselves; it makes a great display of its poverty and turns the yawning emptiness into a celebration'. ${ }^{8}$ From the standpoint of class struggle the melancholic image of the death, pain and sacrifice of 'enslaved ancestors' fosters class hatred, 'the destructive energies', to redeem past sufferings and atrocities. The melancholic spleen of avenging the dead stand in sharp contrast to moral exhortations of Christian forgiveness and 'liberated grandchildren' put about by social democracy. ${ }^{9}$ Belief in an absent future, what Benjamin called the 'sclerotic liberal moral-humanistic ideal of freedom', only serves to pacify and console the working class to make their peace with intolerable conditions in the present. ${ }^{10}$

Against the brooding, petrified melancholia of the allegorical image Benjamin posited the dialectical image. Where allegory is subjective and arbitrary, inducing political passivity, empathy and self-alienation, the dialectical image is objective and concrete, a shocking flash bursting through the seamless eternity of the commodity system demanding political urgency.

It is not what is past casts its light on what is present, or what is present its light on what is past; rather image is that wherein what comes together in a flash with the now to form a constellation. In other words: image is dialectics at a standstill. ${ }^{11}$

Against capital's own insistence on forward movement, ceaseless unrest, linear accumulation of labour time, and so on Benjamin wanted to call a halt, a

\footnotetext{
${ }^{8}$ Benjamin 1931, p. 425.

${ }^{9}$ Benjamin 1973a, p. 252.

${ }^{10}$ Quoted by Pensky 1993, p. 198.

${ }_{11}$ Benjamin 1999c, p. 463.
} 
revolutionary stop-off to arrest the calamities wrought by capitalism. As Max Pensky summarises this new sense of political quickening,

The continuum of history gives up its images and loses its grip upon them; in the process it loses its grip upon the collective consciousness as well. The sudden appearance of the commodity, no longer an archaic wish image, but a startling dialectical image, is the moment when the image is rescued from its consignment to the 'continuity' of repetition and also the moment when this continuity is revealed as mythic. ${ }^{12}$

Immediately it appears within the juxtaposition of fragmented historical images, the critic must be fully prepared beforehand to recognise this chance and take up a new relationship of proximity to the montage of fragments.

The construction of montages of historical trash provides a portal or a medium for this proximity to find a form of concrete expression ... Moreover, the critic must also be in a position to effect the representation of this moment through the juxtaposition of fragments culled from the 'reject' heap of capitalist modernity. ${ }^{13}$

Allegorical melancholia is not so much abandoned here as radicalised by the dialectical image's power to bring forward acute contradictions for involuntary, but accurate recognition and diagnosis by the receptive critic. ${ }^{14}$ Like Marx's analysis of the commodity form as the primary unit through which the whole of capitalism is condensed, Benjamin saw that the image of a single artwork can condense a full life

${ }^{12}$ Pensky 1993, p. 217. 
and, in the full life, a specific era and, in the era, the entire course of history. ${ }^{15}$ Surrealism's great merit is precisely its potential for 'profane illumination' to provide 'a materialistic, anthropological inspiration'. Still Benjamin cautions against an excessive faith in Surrealism's 'mysterious side of the mysterious'. That, he argues, 'would be to subordinate the methodical and disciplinary preparation for revolution entirely to a praxis oscillating between fitness exercises and celebration in advance' ${ }^{16}$ The hidden side of the revolutionary uncanny should encourage neither empty formal rehearsals nor premature grandiose self-congratulations. Surrealism remained at the level of radicalising the surface appearance of capitalist modernity that, for Benjamin, gave rise to excitable mood swings instead of patiently undertaking materialist criticism of 'modern mythology', to read capitalist phantasmagoria as hieroglyphic clues to alienated social life. The detailing of the refractory material of social conditions is not a matter for the passive contemplation of mind, a psychologisation of the world that leads intellectuals to succumb so easily to all manner of magical illusions. Adorno repeatedly worried that Benjamin's separation of the fragment from the totality of the always-the-same 'hell' of capitalist modernity merely fetishised, and hence soothed, the pain and dampened the unforgiving response of the dominated class. ${ }^{17}$ It is fair to say that Benjamin had little time for consolation prizes of the kind that left-wing melancholia awards itself - magical aesthetics as psychic compensation for the collective failure to confront the rubble heap of history. As Benjamin put it in 'The Author as Producer', his 1934 address to the Institute for the Study of Fascism in Paris, the 'magic strength' of fascism depended upon the self-delusions of psychologism:

\footnotetext{
${ }^{13}$ Pensky 1993, p. 219.

${ }^{14}$ Jennings 1987.

${ }^{15}$ Benjamin 1973a, p. 254.

${ }^{16}$ Benjamin 1997, p. 236.
} 
The mind which believes only in its own magic strength will disappear. For the revolutionary struggle is not fought between capitalism and mind. It is fought between capitalism and the proletariat. ${ }^{18}$

Instead, the mysterious can only be understood 'by virtue of a dialectical optic that perceives the everyday as impenetrable, the impenetrable as everyday' ${ }^{19}$ Against the optimistic metaphors of ‘metaphysical materialism' Benjamin's ‘anthropological materialism' posits the 'dialectical annihilation' of artistic contemplation by a technologically-organised 'sphere of images and, more concretely, bodies' ${ }^{20}$

Only when in technology body and image so interpenetrate that all revolutionary tension becomes bodily collective innervation, and all bodily innervations of the collective become revolutionary discharge, has reality transcended itself to the extent demanded by the Communist Manifesto.

'Innervation' for Benjamin is a neuro-physiological process of positive and imaginative work by the sensorium as it mediates the resistant, repetitive material of the external world..$^{21}$ Benjamin gives the instructive example of Brecht's 'alienation effect', which sought to dispel naturalistic illusions in epic theatre by deploying thought-inducing and therapeutic interruptions to ordinary, habitual action such as laughter, that 'most international and revolutionary emotion' ${ }^{22}$

${ }^{17}$ Benjamin and Adorno 1999.

${ }^{18}$ Benjamin 1977, p103.

${ }^{19}$ Benjamin 1997, p. 237.

${ }^{20}$ Benjamin 1997, p. 239.

${ }^{21}$ See Buck-Morss 1992, p. 17, n.54; Bratu Hansen 1999, p. 313.

${ }^{22}$ Benjamin 1929a, p. 224. 
Film's technical apparatus provides for such a dialectical optic. Cinematic recognition of the self-alienation forged by the rule of capital is two-sided: 'allegorical, in the sense of making the dilemma visible, readable in materialist terms (which includes the way technology perpetuates, instead of overcoming, sensory alienation); and utopian, in the sense of compensation for the anthropological lack (without denying it) by rehearsing a collective innervation of technology'. ${ }^{23}$ Benjamin notes how cinema technically re-constructs new 'synthetic realities' out of extended temporality and fragmented space. Cinema's rapid sequence of framed images re-orders the spatial imagination of spectators, restructuring cognitive processes into an 'opticalunconsciousness', paralleling the 'unconscious impulses' explored by psychoanalytical therapy. ${ }^{24}$ Filmic technique matches and even exceeds the increased visual and aural speed of urban sensibilities, providing the optical-unconscious with accurately reproduced external surfaces that bring ordinarily unnoticed physical spaces to the eye's attention. Post-production film appears to 'naturally' reflect immediate reality, its technological mediation obscured 'precisely because of the thoroughgoing permeation of reality with mechanical equipment' ${ }^{25}$ Film elevates mimetic copying to a technical principle, consciously isolating and organising into sequential narrative form what everyday experience registers as a chaotic jumble of barely comprehended, fleeting detail.

Cinema and the urban shock absorber

\footnotetext{
${ }^{23}$ Hansen 1993, p. 46.

${ }^{24}$ Benjamin 1973b; Leslie 2000, p. 57.

${ }^{25}$ Benjamin 1973b, p. 227.
} 
An elective affinity between cinema and the city forms the basis of Benjamin's famous 1936 essay 'The work of art in the age of mechanical reproduction'. ${ }^{26}$ Esther Leslie neatly summarises this constellation: 'There exists a special intimacy between film as form, cinema as an institution and city life as a social phenomenon' and, it might be added, shock-mediated perception. ${ }^{27}$ Benjamin attacked 'ultra-reactionary authors' who forcibly read the ritual elements of traditional aesthetics into film and who complained of 'the sterile copying of the exterior world with its streets, interiors, railroad stations, restaurants, motorcars, and beaches which until now has obstructed the elevation of the film to the realm of art' ${ }^{28}$ Film is the most perfect technology for urban sensibilities used to dealing with the 'dangerous intersections' of human traffic in a big city.

Moving through this traffic involves the individual in a series of shocks and collisions ... Baudelaire speaks of a man who plunges into the crowd as into a reservoir of electric energy. Circumscribing the experience of the shock, he calls this man "a kaleidoscope equipped with consciousness" ... In a film, perception in the form of shocks was established as a formal principle. ${ }^{29}$

Both cinema and the city 'kaleidoscopically' militate against passive contemplation. Unlike the contemplative gaze of the tourist before a famed building, for the distracted city dweller architecture is observed only incidentally and absent-mindedly. Spatial consciousness passes over to an optical unconsciousness. As soon as

\footnotetext{
${ }^{26}$ Benjamin 1973b. Nuances and emphases in different translations of the 'Artwork' essay have influenced different interpretations of the relationship between technology, aesthetics and politics. See Hansen 1987.

${ }^{27}$ Leslie 2000, p. 67.

${ }^{28}$ Benjamin 1973b, p. 221.

${ }^{29}$ Benjamin 1973c, p. 171.
} 
movement in this environment becomes 'second nature' 'the rigorous connection between foreground and distance ... vanishes at a stroke like the facade of a house as we enter it' ${ }^{30}$ Here Benjamin draws directly on Simmel's study of the blasé urban personality. ${ }^{31}$ Unmindful banal habits are largely determined by the repeated obstructions and distractions of haptic, tactile urban experience. Benjamin connects this 'optical unconsciousness' to a certain kind of industrial labour deprived of inner life by the repeated shocks perpetrated by mechanized labour processes. As the habituated appendage of the machine the urban proletarian becomes 'a mimetic shock absorber'. Leslie notes how shock is complemented by its opposite - 'numbness':

Numbness - the shock repeated until it becomes no longer a shock but the norm causes insensibility, an effect of the psychic necessity to parry the blows and of the repetitive nature of labour ... displaying simultaneously an alertness (a preparedness to perform) and a numbness (an emotional disinvestment). ${ }^{32}$

In developing Benjamin's insight into corporeal numbness Buck-Morss connects modern aesthetics to anaesthetics. ${ }^{33}$ Anaesthetics provides the corporeal sensorium with an 'elaborate technics' to defensively parry shocks to the psyche and the body.

\footnotetext{
${ }^{30}$ Benjamin 1997, p. 78.

${ }^{31}$ Frisby 1985. In his correspondence with Adorno Benjamin termed Simmel a 'Cultural Bolshevik'. Benjamin and Adorno 1999. This goes too far. Elsewhere, Benjamin called Simmel's masterpiece, The Philosophy of Money, 'the petty-bourgeois theory of labour'. 1999d, p. 660. Nevertheless, Simmel's influence extended over Lukacs, Bloch, Kracauer and Mannheim, as well as Benjamin. See Leck 2000. Simmel was a Cultural Bolshevik only in the sense of his militant modernism but is perhaps more accurately situated between Marx, Kant and Nietzsche. It was the latter two influences that loomed for Volosinov in Simmel's approach to the 'tragedy' of bourgeois culture: 'the vital dialectical contradiction between the psyche and existence assumes for Simmel the shape of an inert, fixed antinomy - a "tragedy", and he endeavors in vain to surmount that inevitable antimony by resorting to a metaphysically colored dynamics of the life process'. 1973, p. 40. Benjamin's dialectical image rejects the rigid separation into the spheres of inner life and the purely external, and unfathomable, 'thing-in-itself' of outer life.

${ }^{32}$ Leslie 2000, p. 183.
} 
Memory and sensuality are sundered from responses deadingly conditioned and drilled to sift the flood-tide of sense stimulation induced by the "phantasmagoria' of technological manipulation. Cinema does not merely reflect this condition but reforms it, acting as the twilight occasion for consciousness's awakening from the eternal repetition of capitalist dream-time.

Cinema not only records images but also reveals something of the shocking significance of the ordinary details of everyday life to the optical unconsciousness. The Russian Formalist Victor Shklovsky also distinguished between everyday 'dimmed perception' and forms of contemplative cognition:

A phenomenon, perceived many times, and no longer perceivable, or rather, the method of such dimmed perception, is what I call "recognition" as opposed to "seeing". The aim of imagery, the aim of creating new art is to return the object from "recognition" to "seeing". 34

Shklovsky has in mind a specialised style of looking trained to resist casual recognition, a heightened way of seeing unfamiliar surfaces rather than how they how they might be usefully known in everyday life. Aesthetic sensation is reserved as an experience disconnected from the habitual and the banal. A sharp cleavage is visited upon everyday, 'algebraic' perception and the poetic 'defamiliarisation' of the artful object. Practical, everyday perception demands an 'economy of energy' where objects are only dimly apprehended 'as though enveloped in a sack'. On the other side, the

\footnotetext{
${ }^{33}$ Buck-Morss 1992.

${ }^{34}$ Shklovsky 1974, p. 114.
} 
artful object demands prolonged, concentrated effort in order to 'recover the sensation of life ... to make one feel things'.

The purpose of art is to impart the sensation of things as they are perceived and not as they are known. The technique of art is to make objects "unfamiliar", to make forms difficult, to increase the difficulty and length of perception because the process of perception is an aesthetic end in itself and must be prolonged. Art is a way of experiencing the artfulness of an object; the object is not important. ${ }^{35}$

Such an approach has obvious affinities with arthouse cinema as a social institution, which demands special training and knowing as the price of entry to what might seem to a popular audience as nothing other than dull, ponderous and boring stylistic affectations. An elitist disdain for 'easy' recognition forgets that 'dimmed perception' arises from the intimacy which the masses have with the petrified forms of everyday life. ${ }^{36}$ Where a revolution in art may overturn conventions, perception, values and sensibilities its relative distance from commodity production and circulation will tend to leave the masses cold and dismissive.

At no point in time, no matter how utopian, will anyone win the masses over to a higher art; they can be won over only to one nearer to them. And the difficulty consists precisely in finding a form for art such that, with the best conscience in the world, one could hold that it a higher art. This will never happen with most of what is propagated by the avant-garde of the bourgeoisie ... The masses positively require from the work of art (which, for them has its place in the circle of

\footnotetext{
${ }^{35}$ Shklovsky 1917, p. 277.
} 
consumer items) something that is warming. Here the flame most readily kindled is that of hatred. Its heat, however, burns or sears without providing the "heart's ease" which qualifies art for consumption. ${ }^{37}$

Art's purity and idealism, its opaqueness, its lack of mediation by the test of generalised commodity relations, makes its mass reception a negative one. Only by taking up cultural forms deeply and immediately entangled in commodity relations, 'kitsch', will art find its way into the homes and hearts of the masses.

Kitsch, on the other hand, is nothing more than art with a 100 percent absolute and instantaneous availability for consumption. Precisely within the consecrated forms of expression, therefore, kitsch and art stand irreconcilably opposed. But for developing living forms, what matters is that they have within them something stirring, useful, ultimately heartening - that they take "kitsch" dialectically up into themselves, and hence bring themselves nearer to the masses while yet surmounting the kitsch. ${ }^{38}$

Just as for Benjamin the critic must be prepared beforehand to see the revolutionary possibilities in the rejected fragments of capitalist modernity, kitsch's reinforcement and defamiliarisation of habituation may yet prepare the masses for a more active form of seeing. Only through glimpsed, conscious re-cognition might the numbness of self-alienation become productive. ${ }^{39}$ Here Benjamin gives film a special dialectical

\footnotetext{
${ }^{36}$ As pointed out by one of the referees of this paper.

${ }^{37}$ Benjamin 1999b, p. 395.

${ }^{38}$ Benjamin 1999b, p. 395.

${ }^{39}$ Hansen 1993, p. 44.
} 
place for technologically mediating the distances from the masses of art and radicalising the direct proximity of kitsch.

Today, perhaps, film alone is equal to the task - or, at any rate, more ready for it than other art form. And whoever has recognized this will be inclined to disallow the pretensions of abstract film, as important as it experiments may be. He will call for a closed season on - a natural preserve for - the sort of kitsch whose providential site is the cinema. Only film can detonate the explosive stuff which the nineteenth century has accumulated in that strange and perhaps formerly unknown material which is kitsch. ${ }^{40}$

After all, film continues the 'drill' of training consciousness in its defensive adaptation to technology. ${ }^{41}$ Film's technical capacity for camera 'lowerings and liftings, its interruptions and isolations, its extensions and its accelerations, its enlargements and reductions' contain subversive potential to revise the habituated experience of shocks and create 'entirely new formations of the subject'. ${ }^{42}$ Mimetic perfection in surface (re)semblance does not determine audience reception in a oneway process. '[B]y exploring commonplace milieus under the ingenious guidance of the camera' mimesis also permits a sense of discontinuity in comprehending dialectically the familiarly routine and sudden exposure to the unexpected,

Our taverns and our metropolitan streets, our offices and furnished rooms, our railroad stations and our factories appeared to have us locked up hopelessly. Then came the film and burst this prison-world asunder by the dynamite of the tenth of a

\footnotetext{
${ }^{40}$ Benjamin 1999b, pp. 395-6.
} 
second, so that now, in the midst of its far-flung ruins and debris, we calmly and adventurously go travelling. ${ }^{43}$

Here Benjamin draws parallels with psychoanalysis. Film helps recover undisturbed dreams and breaks-up the emotional ambiguity of the 'urban shock absorber',

what comes to us when we dream is a new and unprecedented attentiveness that struggles to emerge from the womb of habit. Everyday experiences, hackneyed expressions, the vestiges that remain in a glance, the pulsating of one's own blood - all this, hitherto unnoticed and in a distorted and overly sharp form, makes up the stuff of dreams. ${ }^{44}$

Repressed injuries from a forgotten past only become recoverable as involuntary memory, Proust's memoire involuntaire, at spontaneous moments of fleeting recognition sparked by images that interrupt the seamless flow of the everyday. ${ }^{45}$ Not in the studiously trained gaze at the abstract picture but somewhere in the absent mind's 'dimmed perception', in the half-haze between dream and consciousness, does the awakening sensorium prepare to receive the dialectical image.

Is awakening perhaps the synthesis of dream consciousness (as thesis) and wakening consciousness (as antithesis)? Then the moment of awakening would be identical with the "now of recognizability", in which things put on their true surrealist - face. Thus, in Proust, the importance of staking an entire life on life's

\footnotetext{
${ }^{41}$ Buck-Morss 1992, p. 18, n.62.

${ }^{42}$ Benjamin 1973b, p. 230.

${ }^{43}$ Benjamin 1973b, p. 229.

${ }^{44}$ Benjamin 1932, p. 592.
} 
supremely dialectical point of rupture: awakening ... The realization of dream elements in the course of waking up is the canon of dialectics. It is paradigmatic for the thinker and binding for the historian. ${ }^{46}$

From Benjamin's standpoint film's illusionistic devices and hidden technological artifice might have served as the occasion for the most complete ideological deception about technology and perception. But, as Miriam Hansen puts it, 'Rather than dismissing it for perpetuating the illusion of reality, Benjamin sees the cinematic crossing of supreme artificiality with physiological immediacy as a chance - to rehearse technological innervation in the medium of the optical unconsciousness' ${ }^{47}$ Benjamin's materialism is thus premised upon the intervention of cinema's technical, aesthetic and cognitive potential within an existing cultural repertoire of meaning and contradictory social conditions. This concern with the production of cultural meaning out of the ambiguity of film's technical apparatus and the continuing power of artistic example to expose the artifice underlying the familiar repertoire of modern life, call into question the forms in which the rule of capital contrives its own appearance.

\section{Ratcatcher's utopian realism}

Benjamin's elective affinity between optical unconsciousness and the city remains potentially illuminating for arresting those fleeting moments of child-like recognition thrown up by Lynne Ramsay’s critically-acclaimed film Ratcatcher. ${ }^{48}$ Ratcatcher's imagery of a city buried beneath the allegorical waste of its uncollected rubbish instructively de-familiarises 'the repertoire of modern life'. Filmic technique itself

\footnotetext{
${ }^{45}$ Benjamin 1973d, p. 198.

${ }^{46}$ Benjamin 1999c, p. 463-4.

${ }^{47}$ Hansen 1993, p. 43.
} 
enters as a subject in Ratcatcher's representation of children at a specific historical moment, the dustbin drivers strike of the mid-1970s, in a specific place, Glasgow. Urban landscapes like Glasgow contain a vast variety of messages and clues about the ideological meaning of divided city spaces. Cities are bound-up in a dialectic of 'hard' physical, tactile materiality and 'soft' perceptions and meanings. This dialectic is present in what might be called the 'Glasgow realist film' in pictures like My Name is Joe (1998), directed by Ken Loach, Orphans (1999), directed by Peter Mullen, as well as Lynne Ramsay's Ratcatcher (1999). ${ }^{49}$ Following her prize-winning short films, Small Deaths (1996), Kill the Day (1997) and Gasman (1997), Ratcatcher is the first feature written and directed by Lynne Ramsay. It has been compared to the 'stark poetry' of Ken Loach's Kes 'in the way it captures the domestic minutiae of childhood and in its portrayal of young lives prematurely disjointed by the encroachments of the adult world' ${ }^{50}$ However, far from aspiring to the observational distances of classic narrative realism typical of Loach's films, Ramsay's film is pervaded by a fantastical, intimate form of realism that deploys close-ups, photographic stillness and silences. Influenced by cinema such as Maya Deren's avant-garde film Meshes of the Afternoon (1943) and Robert Bresson's 'gnomic catechism', Notes on the Cinematographer, Ramsay's intuitive experimentation 'very consciously avoided social realism' but equally eschewed 'the postmodern cut-andpaste job' 51

\footnotetext{
${ }^{48}$ See, for example, the effusive reviews, and some negative ones, compiled by the website Rottentomatoes 2000.

${ }^{49}$ Classical realism and left-wing politics have, unreasonably, been seen to posses a special affinity. Politically, Loach is a well-known socialist of long standing and Mullen is a member of the left-wing Scottish Socialist Party. Mullen has been critical of Loach's more naturalistic form of realism, preferring to work within what he describes as 'magical realism'.

${ }^{50}$ O'Hagan 1999

${ }^{51}$ Quoted in Francke 1999, pp. ix, xiv. See also McKibbin 2000.
} 
Nevertheless Ratcatcher still aspires to some kind of realism. In all its multiple uses realism is taken to refer to 'the real' at some level, to claims about a 'reality' amenable to perception from the visual evidence that the camera puts in front of our eyes. Conventionally, a binary opposition is posited between realism and formalism. In the Lukacsian tradition 'realism' treats the technical medium as a more or less 'neutral' window for looking at social action while 'formalism' subordinates content to a more or less 'neutral' aesthetic criteria. In the classic urban realist film the physical materiality of city spaces folds into the narrative to both enclose and circumscribe and disclose and unfold cinematic themes, plot and characterisation. ${ }^{52}$ Conventional narrative cinema elevates a distant 'typicality' over 'particularity' and transforms place into a functional setting, as a site for action. An impersonal, 'authorless' narrative unfolds from no place in particular. Empirical observation alone instructs the viewer to see things 'as they really are'. The 'realist' technique of 'distanciation' in cinema works in a double sense: as, first, a 'distance' established between observer and observed by, second, a boarded-up narrative 'distance' from the places put on view. Benjamin noted that naturalistic realism tends to collapse the 'struggle against misery' into an object of contemplative consumption. ${ }^{53}$

On the other hand, other kinds of realism more readily foreground place through fantastic imagery and close-up detailing of urban exteriors and domestic interiors. As Hill argued for some earlier British New Wave films, 'despite the claim to realism, the directorial hand is not hidden in the folds of the narrative but [is] "up front", drawing attention to itself and the "poetic" transformation of its subject matter'. ${ }^{54}$ Yet just as the political commitment of social realism is, on its own, insufficient any

\footnotetext{
${ }^{52}$ Hill 1986, and 2000.
} 
reification of formal technique runs the risk of subordinating 'reality' to aesthetic criteria and elevating formal technical issues over ideological ones. One form this takes is to render the commodification of labour and the conditions of the capitalist labour process invisible and incomprehensible, creating a disjunction between character and the social relations they inhabit. In so doing Formalism readily accedes to the 'mystery' of abstraction. James Donald, for example, objects to Siegfied Kracauer's negative comparison of the formalist aesthetics in Walter Ruttman's Weimer film Berlin to the permeation of abstract, 'formal rhythms' with 'communist ideas' and 'revolutionary convictions' in Dziga Vertov's Soviet film Man with the Movie Camera. 'Kracauer seems to rule out of court the concern for ambivalence and the uncanny that must be central to the unconscious optics of modernism' ${ }^{55}$ In a common move Donald invokes the post-modern version of Benjamin to de-politicise filmic aesthetics. But should 'ambivalence and the uncanny' be erected into a formal principle in clear opposition to tendentious art? As Benjamin reminds us, formal artistic experimentation 'was almost always a flag under which sailed a cargo that could not be declared because it still lacked a name'. ${ }^{56}$ In other words, experimental ambivalence is a flag of convenience that expresses an inability to fix cultural forms to ideological content once and for all, while the as yet undeclared 'cargo' of utopian irruption continues to make ideological smuggling necessary.

A film like Ratcatcher steers a course between tendentious forms of realism and abstract formalism. Some, like Alex Giliken, propose a 'solution' to the 'difficulties' of Ramsay's realism by locating it somewhere between British narrative realism and

\footnotetext{
${ }^{53}$ Benjamin 1977, pp. 96-7.

${ }^{54}$ Hill 1986, p 132.

${ }_{56}^{55}$ Donald 1999, pp. 81-2, and Kracauer 1947, pp. 185-7.

${ }^{56}$ Benjamin 1997, p. 231.
} 
more elliptical modernist art cinema, 'its fissures of narrative, tone and subjectivity may lie between two readings of the film: that it belongs to the tradition of Loach, Richardson and Clarke; and that it sits equally comfortably within the traditions of Douglas, Davies and Malick' ${ }^{57}$ Other critics found the film 'a beguiling paradox ... It is an unmistakable masterpiece, yet it resists conventional exegesis' ${ }^{58}$ Searching for a convenient nomenclature, the term 'expressionism' was used by some critics to pigeon-hole the film. Charles Taylor typified the views of many:

Ramsay works in a style that might be called introverted expressionism; everything is muted, cooled out, tamped down. It's a film that seems entirely composed of bleak landscapes, static shots of faces with slugged-out expressions, a nearly fetishistic attention to grime and scabs and decay. ${ }^{59}$

The Scottish context of the film is repeatedly remarked upon. Ramsay is conveniently filed under 'the honourable tradition of narrative Scottish cinema' ${ }^{60}$ Giliken generalises this still further into 'a strongly Scottish tendency to locate the numinous, the uncanny or the daemonic, not at the margins of the narrative, but at its heart' ${ }^{61}$ Too often this descends into an excuse for nationalist self-conceit and braggadocio about a new 'national tradition' in cinema, something Ramsay balks at. More justifiably, Ramsay may, however, be instructively compared to the sparse, elliptical style of Bill Douglas, the Scottish director of the autobiographical film trilogy, $M y$ Childhood (1972), My Ain Folk (1973) and My Way Home (1978). For the historian of Scottish 'national cinema', Duncan Petrie, 'Ratcatcher is an exercise in restrained

\footnotetext{
${ }^{57}$ Giliken 2001, p. 16.

${ }_{58}^{58}$ Gilbert 2001.

${ }^{59}$ Taylor 2000.

${ }^{60}$ Gilbert 2001.
} 
austerity recalling the brooding contemplation and paired-down aesthetic of Bill Douglas'. ${ }^{62}$ Yet in terms of technique and politics the parallels between Ramsay and Douglas can be over-drawn. Where Ramsay eschews overt political commitment Douglas did not shy away from class politics. Despite critical acclaim Douglas was effectively marginalized until his much too early death in 1991, raising the finance for just one other film, Comrades (1987), on the solidarity of and cruelties meted out to the Tolpuddle Martyrs. Though echoing Douglas's photographic stillness Ramsay's visual style is more varied and eclectic, marshalling a range of camera angles, jump cuts and shifting depth of field. ${ }^{63}$ Ramsay's cinematographer, Alwin Kulcher deploys the camera with unflinching poise and, with Benjamin's dictum about exemplary technique in mind, generally avoids showy moves that call unnecessary attention to the technical apparatus.

Ramsay's concern with an instructive technical apparatus begins to meet Benjamin's injunction in the 'Author as producer' that the 'correct political tendency' of a work includes the quality of its technique and innovation and does not reside merely in the expressed political intentions of the work. Technique is the proper starting-point for dialectically transcending 'the sterile dichotomy of form and content' ${ }^{64}$ An improved technique acquires 'an organising function' by prescribing the conditions of its own reception. The work takes on the status of an exemplary model whose 'mediating effectiveness' teaches other producers to reflect upon their position in the production process and adapt it to the service of the proletarian revolution. We will argue that while Ratcatcher falls short on these imposing strictures, in its failure to address the

\footnotetext{
${ }^{61}$ Giliken 2001, p.17.

${ }^{62}$ Petrie 2000, p. 216.

${ }^{63}$ Petrie 2000, p.217.

${ }^{64}$ Benjamin 1977.
} 
class politics within which it is set and its view of children as a kind of moral putty, it nevertheless shows to other producers something of film's continuing potential to freeze and unmask self-alienation.

This is not how humanist liberals want someone else's poverty depicted for them. Some critics, like Taylor, argue that Ramsay's arm's -length compassion for her characters prevents her from bringing them close to the audience:

Ramsay is trying to avoid the unintentional humanitarian condescension that often mars movies of the poor ... The trouble is she doesn't do anything to bring her characters close to us. She's right to be suspicious of sociological bromides that presume to explain the mysteries of personality, but for all we learn about these characters they have never been otherwise and will ever be thus ... The hurt and unspoken pain in James' eyes make you want to feel close to him, but Ramsay's episodic, imagistic approach keeps us from getting to his core. Her technique takes the place of his voice instead of articulating it. The cruel realizations that Ramsay piles on James at the end of the film feel plausible and accurate but not emotionally earned. It's unfair to be asked to suffer for a character we've been kept at a distance from. And, paradoxically, for all her poetic touches the movie feels more bounded by the particulars of poverty than the naturalistic approach of De Sica and Ray, which transcended realism to achieve poetry. ${ }^{65}$

Taylor wants to see work that erases the barriers between the audience and impoverished screen characters. His exemplary models are Vittorio De Sica's

\footnotetext{
${ }^{65}$ Taylor 2000.
} 
Shoeshine, Umberto D and The Bicycle Thief and Satyajit Ray's The Apu Trilogy.

This is a desire 'to transcend realism' in the name of empathy with poor - to 'want to feel close', 'to be asked to suffer', to absorb poverty 'poetically' - all excellently blocked by Ramsay's technique - which 'prevent us from getting to his core', 'cruel realizations not emotionally earned', 'kept at a distance from', and so on. Ramsay frustrates strategies for the liberal-humanist co-option of the inner-life of the poor in favour of showing the concrete conditions of unsparing brutality, ensuring that her cinematic framing is indeed 'bounded by the particulars of poverty'. Humanist empathy wishes to possess the poor for the 93 minutes length of the film, experience despair, escape and resistance in a manner that it is accustomed to, and parade a refined sensibility to feel on behalf of the poor. Empathy breaks down the dialectical image, deflecting the shockwaves that the image's unreconciled fragments send out, dispersing anger at the brutish callousness that capitalist modernity inflicts as a matter of routine.

\section{Ratcatcher's Children and Magical Urbanism}

At the heart of both Benjamin's dialectic of self-alienation and Ratcatcher's imagery is the worldview of children. Ramsay views childhood as free of 'moral baggage' and 'a blank canvas' for dramatically exposing the absurd world of adulthood. ${ }^{66}$ For Benjamin, 'What is truly revolutionary is the secret signal of what is to come speaks from the gesture of the child' ${ }^{67}$ Buck-Morss makes the inflated claim that 'No modern thinker, with the exception of Jean Piaget, took children as seriously as Benjamin in developing a theory of cognition'. ${ }^{68}$ Yet Benjamin's view of active, reciprocal child cognition comes close to Lev Vygotsky's critique of Piaget's

\footnotetext{
${ }^{66}$ Quoted in Francke 1999, p. viii.
} 
'mechanical abolition' of the child's spontaneous thought by external abstract instruction. ${ }^{69}$ Rather than being a process of Freudian repression - 'a late development, an effect of a high differentiation of consciousness' - Vygotsky's paedology distinguishes children's non-conscious functions from conscious functions: 'We use consciousness to denote awareness of the activity of the mind - the consciousness of being conscious' ${ }^{70}$ For Vygotsky the primary image-complex is rubbed-away by conceptual naming:

In the contest between the concept and the image that gave birth to the name, the image gradually loses out; it fades from consciousness and from memory, and the original meaning of the word is eventually obliterated .... The primary word is not a straightforward symbol for a concept but rather an image, a picture, a mental sketch of a concept, a short tale about it - indeed, a small work of art ... In this respect the process of language creation is analogous to the process of complex formation in the intellectual development of the child. ${ }^{71}$

Only the material recovery of utopian images motivate the collective into action, what Benjamin calls 'innervation' - 'like the child who learns [the practical task of] grasping by trying [impossibly] to catch the moon in its hands' ${ }^{72}$ Similarly, Vygotsky aims to observe the unobservable 'other side of the moon' of inner thought and speech

\footnotetext{
${ }^{67}$ Benjamin 1929, p. 206.

${ }^{68}$ Buck-Morss 1989, p. 263.

${ }^{69}$ Vygotsky 1962, p. 83-7. Buck-Morss notes that Benjamin studied Vygotsky, Piaget, Sassaure, Cassier among others in his review of the sociology of language, 'Probleme der Sprachsoziologie'. (1989, p. 495 n.76)

${ }^{70}$ Vygotsky 1962, p. 91.

${ }^{71}$ Vygotsky 1962, pp. 74-5.

${ }^{72}$ Benjamin, quoted by Buck-Morss 1989, p. 117. See also Buck-Morss, 1992.
} 
processes. ${ }^{73}$ Benjamin emphasises the relationship between cognitive images and revolutionary praxis to bring 'profane illumination' to 'the mystery of the mysterious'. Concrete images 'vitalize the will. The mere word, by contrast, at most inflames it, to leave it smouldering, blasted. There is no intact will without exact pictorial imagination. No imagination without innervation'. ${ }^{74}$

Ratcatcher's pictorial imagination reaches for the kind of profane illumination described in words by Benjamin. Sean O'Hagan describes the film as 'visually poetic and loaded with meaning. It speaks of childhood reverie, of domestic claustrophobia, and of death, both real and metaphorical'. ${ }^{75}$ Ramsay explicitly set out to 'make a film that was driven by emotion and images rather than narrative'. ${ }^{76}$ Even the script is conceived by Ramsay 'only as a working document, a guide' ${ }^{77}$ In both exterior and interior settings fleeting details are suspended in time. Material objects are redeemed by attentiveness to their social significance. Melancholia is manifest in the use made by the central child character, James, of everyday physical material. Table salt becomes raw material for abstract doodling on the kitchen table and individual puffed rice breakfast cereal are carefully fastened to his Da's sleeping face and gaping mouth. 'Breathing spaces' are created by letting the camera 'run and see what happens', disrupting audience film training for the 'phantasmagoric' shocks of rapid 'bam-bam-bam' sequences. ${ }^{78}$ For Benjamin breathing is 'the most delicate regulator' of innervation, allowing 'exact pictorial imagination' to supplant the 'mere word' ${ }^{79}$

\footnotetext{
${ }^{73}$ Vygotsky quoted by van der Veer and Valsimer 1991, p. 364.

${ }^{74}$ Benjamin 1997, p. 75.

${ }^{75}$ O'Hagan 1999.

${ }^{76}$ Quoted in Spencer 1999, p. 17.

${ }^{77}$ Quoted in Francke 1999, p. xiii.

${ }^{78}$ Quoted in Francke 1999, p. xi.
} 
From the opening slow motion shot of a twisted net curtain unravelling to reveal a young boy absent-mindedly releasing himself from death-like concealment, Ratcatcher trades on the lyrical impressionism of poetic imagery. As Ramsay describes the scene in the original script: 'Ryan (eleven years old) stands at the window. He has pulled the yellowing net curtain over his head like a shroud. He spins round and round, cocooning himself in it' ${ }^{80}$ Such hiding-play represented for Benjamin children's sensuous absorption into the material world, 'enclosed in the world of matter', compared to the detached alienation of adult commodity fetishism: 'Standing behind the doorway curtain, the child becomes himself something floating and white, a ghost ... Anyone who discovers him can ... weave him forever as a ghost into the curtain'. ${ }^{81}$ That Ratcatcher's 'little Egyptian mummy of curtain' is immediately smacked on the head by his mother even before he is completely free establishes that brutality and beauty are not opposites and that serene order can be suddenly disrupted by unexpected bangs to the head. ${ }^{82}$ The camera dwells on the slow unwinding of the curtain well after Ryan has bolted out of it. Unconventionally, soon after establishing Ryan's character at the film's beginning he is killed off very early and replaced by a second central character, James. From the start, the viewer struggles to establish a stable point-of-view through which to observe the pictorial imagery.

Ratcatcher depicts childhood lived at subsistence level among urban decay, violence and burgeoning sexual curiosity. An open-ended, permeable narrative tells the melancholic story of a twelve year old boy, James Gillespie, who playfully pushes his friend, Ryan Quinn, into the canal. Tragically, Ryan drowns. James is haunted by

\footnotetext{
${ }^{79}$ Benjamin 1997, p. 75.

${ }^{80}$ Ramsay 1999, p. 3.

${ }^{81}$ Benjamin 1997, p 74.

${ }^{82}$ Ramsay 1999, p. 3.
} 
guilt and withdraws from his family. James only relates to other vulnerable children like Margaret Anne, who is being sexually abused by a local gang of boys, and Kenny, who has pronounced speech difficulties. Mysteriously, James' sister Ellen is seen catching a bus to an unknown destination. When James follows her he discovers a new, semi-rural housing estate. Meanwhile, James' father, George Gillespie, is elevated into a local hero after rescuing ten-year old Kenny from the canal. George is slashed by a gang of youths after holding a small girl's pup as she goes to the ice cream van. Back home, a family party in his honour abruptly ends when a bloodied George again picks on James and slaps his mother. James runs away, finding solace, first, with Margaret Anne and, then, at the new housing estate. James finally returns home to find that the bin strike has ended and that the rubbish has been removed by the army. He also discovers Margaret Anne having sex with the older boys. Angry and hurt James picks a fight with Kenny who blurts out that he saw James 'kill' Ryan. We next see James throw himself into the canal. In the final scene the whole family, including the dead boy, James, are seen coming over a golden wheat field to arrive at their new house.

Although originally scripted for the Maryhill district of Glasgow the film was shot on location in Govan, a working class area with a poor reputation. ${ }^{83}$ Ramsay brought her own experience to bear on the film. Her family moved out of Maryhill to Summerston on the outskirts of Glasgow when she was five: 'Two toilets and a bath - it was strange, it was like paradise' ${ }^{84}$ Ratcatcher's exterior details provide a sense of place, though Ramsay wants to avoid being seen as 'parochial' since 'this place exists all over but in different forms'. Nevertheless, her original script names precise locations

\footnotetext{
${ }^{83}$ Damer 1989.
} 
within Glasgow: Kintra Street, Duke Street Canal, Firhill Basin Towpath, Easterhouse, Summerston Field, Blackhill Road, right down to the accuracy of the number 61 bus. The street where the film was shot housed 'problem families' waiting to be re-located and was scheduled to be torn down. Locals told the set people, 'Don't bring the rats, we've already got them' ${ }^{85}$ During shooting some locals threatened to steal the equipment. ${ }^{86}$ Though nothing happened it added to a vaguely menacing atmosphere.

\section{Images, words, sound}

Poverty is visually indexed in the film by unevenly combined domestic interiors and clothing: 'In the kind of environment we were describing, people would not be wearing bang-up-to-date clothing or have bang-up-to-date furniture. We mixed elements of the fifties, sixties and seventies; ironically it looks more authentically seventies'. ${ }^{87}$ 'Authentically seventies' or not, the vaguely dated abandoned fashion projects, 'kitsch', releases memory from the brooding, mournful side of melancholia, its shocking juxtaposition re-energising dead artefacts. At one stage, Benjamin saw in the Surrealist leader Andre Breton the first to fully animate revolutionary melancholia out of 'destitution - not only social but architectonic, the poverty of interiors, enslaved and enslaving objects - can suddenly be transformed into revolutionary nihilism'. ${ }^{88}$ In one scene, we are shown a close-up of twelve-year old James tenderly covering-up his sleeping mother's exposed toe cutting through her laddered tights. So enlarged, the

\footnotetext{
${ }^{84}$ Quoted in Romney 1999.

${ }^{85}$ Author interview with Lynne Ramsay, 6 May 2000.

${ }^{86}$ Romney 1999.

${ }^{87}$ Quoted in Francke 1999, p. ix.

${ }^{88}$ Quoted by Pensky 1993, p. 192.
} 
camera endows the banal materiality of fabric texture with the social significance of poverty and childish devotion. ${ }^{89}$ As one reviewer noted of minuscule material detail:

Ratcatcher makes you see the world with bigger eyes, revealing the layers beneath every surface. We're frequently asked to notice materials in conjunction with each other: flesh beneath curtain fabric, a bathtub beneath plastic, a toe beneath nylon, spectacles beneath water. $^{90}$

Ratcatcher's almost photographic attention to expressive spaces and 'minuscule detail' likewise renders dialogue 'almost superfluous' for Ramsay. ${ }^{91}$

People rarely say what they mean. I don't often rely on dialogue as the key to a scene. I like to use silence and physical space to indicate how people feel about each other. $^{92}$

Nevertheless, unexpected insight is gleaned from the subversive humour of formally mistaken word use. ${ }^{93}$ Ramsay accents the cinematic superfluity of dialogue in Kenny's halting speech and comedic malapropisms. He says of James's smoking, 'Ye better watch ye don't get lump cancer' and of the rubbish-filled backyard,

\footnotetext{
${ }^{89}$ Stark 2000.

${ }^{90}$ O'Sullivan, 1999:51.

${ }^{91}$ Which is just as well since outside Scotland, the use of the urban Scottish dialect can appear to some like Gilbert 2000, as 'impenetrable'. While Gaelic is rightly subsidised by the state, the urban Scots vernacular, such as Glaswegian, as opposed to 'literary Scots', is seen as a mark of class-based inferiority and stupidity. See Matheson 2002.

${ }^{92}$ Quoted in Francke 1999, p. xi.

${ }^{93}$ Ramsay 1999, p. 57.
} 
Ah'm no allowed to play doon ther. Ma ma says it's an envir, an envir- It's a really mental health hazard.

In a strange Freudian slip, ten year old Kenny tells the adult Mr Gillespie, 'Thanks a lot for savin' ma wife ... Ah mean life'. ${ }^{94}$ Kenny also slurs his mimicking of other boys in describing the abused Margaret Anne: 'You're a pure cow, pure cow, purecow, poorcow, poorcow', and mimics Margaret Anne's 'Fuck off', with 'Fuckodd, Fuckood, fuckodd, fookgod ...' 95 As these examples show, far from being superfluous dialogue retains a facility for anchoring cinematic imagery. As Volosinov argued, while words cannot supplant cinematic imagery 'All manifestations of ideological creativity - all other non-verbal signs - are bathed by, suspended in, and cannot be entirely segregated or divorced from the element of speech' ${ }^{96}$

Ratcatcher's domestic images are also anchored by incongruous use of (recently) dated pop music. In a rare moment of the Gillespie family occupying domestic space together Tom Jones can be seen on black and white television performing a 'frenzied rendition' of 'What's New, Pussycat?'; Anne Gillespie tries to get her children in a party mood by playing Eddie Cochran's rock and roll 'C'mon Everybody' (against the daughters' protestations); images and music conflict as Little Millie's up-beat ska novelty, 'My Boy Lollipop', plays at the moment the slashed father crashes through the door; and Frank and Nancy Sinatra's 'Something Stupid' accompanies a parental dance of the macabre. For a contemporary audience the music, what used to be called 'middle-of-the-road' pop, nostalgic rock n' roll and a one-hit wonder ska novelty, might suggest a lack of taste or simply a retro-hodge-podge of randomly chosen

\footnotetext{
${ }^{94}$ Ramsay 1999, p. 82.
} 
sounds. The pre-punk Gillespie family might settle down together to view 'Tom Jones Live at Las Vegas' on television but are split by age and gender when Eddie Cochran cackles from the record player. James' sister demands to hear Tom Jones, who is judged to be 'shite' by James. Musical preferences are argued over and negotiated in the family living room. Their pensioned investment in a discarded pop song like ' $\mathrm{My}$ Boy Lollipop', released ten years before the film's own period piece, takes on a new, shocking level of meaning and intensity when juxtaposed to images of domestic apocalypse. Film music's conventional role as ever-present wallpaper deploys nondiagetic soundtracks as dramatic counter-point, following or anticipating the camera to elicit preferred 'voluntary' responses in the viewer/hearer. In contrast, Ramsay's diagetic use of 'My Boy Lollipop' to accompany a traumatic domestic scene creates not a 'sincere' empathetic response but an anempathic construction in the song's cold indifference to the harrowing visual imagery. Audience perception is pulled in different ways by sound and vision, the contradiction left momentarily unresolved. In its apparently kitsch triviality the song becomes shockingly detached, indifferent to suffering, made worse since this is the character's own choice as a consumer of happy music As kitsch the song brings the audience nearer, warming the 'heart's ease' at its exuberance until the barbarism beyond crashes through the living room door. This juxtaposition delves into what Adorno called the 'truth content' of music, its surplus meaning residing beyond the thrall of its second nature familiarity through extramusical signification. ${ }^{97}$ Disruption suddenly exposes Millie Small's message of lively,

\footnotetext{
${ }^{95}$ Ramsay 1999, p. 101.

${ }^{96}$ Volosinov 1973, p. 15.

${ }^{97}$ Adorno 1984.
} 
child-like appeals to undying love $\mathrm{e}^{98}$ as the inverted camera obscura of callous social conditions.

\section{Play and waste}

Ratcatcher's child-centred perspective returns the spectator-collaborator to their own past, to see things 'for the first time' before 'play is transformed into toil, curiosity into fetishism, reciprocity into tyranny, spontaneity into drudgery' ${ }^{99}$ Accumulated rubbish during the bin-drivers strike affords allegorical material for a correspondence between a child's eye and a camera's eye view. As Benjamin noted children become super-charged by the detritus of the urban landscape:

In waste products they recognise the face that the world of things turns directly and solely to them. In using these things they do not so much imitate the works of adults as bring together, in the artefact produced in play, materials of widely different kinds in a new intuitive relationship. Children thus produce their own small world of things within the greater one. ${ }^{100}$

In the city children inhabit a political economy of waste. Children's play prises utopian possibilities out of discarded, worn-out, obsolete objects that only recently circulated as fetishisized commodities. As Gilloch puts it, 'The adult humiliates him

\footnotetext{
98 Adorno would undoubtedly have some harsh words to say about this kind of kitsch pop song's musical aesthetics as monotonous and bereft of meaning. 'My Boy Lollipop' was an anglicised version of mid-1960s Jamaican ska. A cover of Barbie Gay's R\&B hit, it was released in 1964 and sold six million copies worldwide, reaching number 2 in the UK charts and number 5 in the USA. Millie Small, then a Jamaican of uncertain age, cut the song with English-based musicians and producers, 'so was far more likely to be appreciated by British pop-tuned ears. Ears that would still find it difficult to make the jump from crisply recorded very familiar sounds to the often rough 'n' ready Kingston variety', according to the historian of reggae Lloyd Bradley (2000, p. 151).

${ }^{99}$ Gilloch 1996, p. 91.
} 
or herself before the commodity; the child is humiliated by it'. ${ }^{101}$ From contemporary photographs of the Glasgow bin-drivers strike Ramsay links children's use of the accumulated detritus to the insights of surrealism: 'they were quite surreal - kids pulling things from the rubbish, dressing up, finding old dolls, killing rats. It sounds grotesque [but] people were really poor (the pictures sometimes look mediaeval) and people still are'. ${ }^{102}$ Children imaginatively re-form this environment through insightful imitation.

Children's play is everywhere permeated by mimetic modes of behaviour, and its realm is by no means limited to what one person can imitate in another. The child plays at being not only a shopkeeper or a teacher, but also a windmill and a train. ${ }^{103}$

In one scene, Kenny runs in front of James, 'arms outstretched like an aeroplane'. ${ }^{104}$ Dialogue specifies that he is not imitating an aeroplane at all but a bird and, unable to physically leave the ground, has in his mind a particular kind of bird: 'Ah'm a bird, Ah'm a bird, Ah'm an ostrich. Ostrich canny fly', and makes an imitative flapping motion with his arms. In another sense Kenny's play trades on an ostrich-like compromise with grounded conditions, not quite rising to the level expected by Vygotsky: 'Play contains in a concentrated form, as in the focus of a magnifying glass, all developmental tendencies; it is as if the child tries to jump above his usual level'. ${ }^{105}$ Vygotsky's dialectical paedology sees children develop qualitatively in play by leaps and bounds. This sense of the dialectical 'leap' is at the heart of Ben

\footnotetext{
${ }^{100}$ Benjamin 1997, p. 52-3.

101 Gilloch 1996, p. 87.

${ }^{102}$ Quoted in Francke 1999, p. viii.

${ }^{103}$ Benjamin 1933a, p. 720. See also1933b, p 698, and 1997, p. 160.

${ }^{104}$ Ramsay 1999, p. 35.

${ }^{105}$ Vygotsky 1933, quoted by van der Veer and Valisner 1991, p. 345.
} 
Watson's claim that CLR James' transcription of Lenin's own notes from Hegel's

Science of Logic forms 'one of the great concrete poems of the twentieth century' ${ }^{106}$

\section{LEAP}

LEAP

LEAP

LEAP

For Ratcatcher's children a dialectic of 'leaps' constitutes a radical break with habitforming 'gradualness', stretching the possibilities within unpromising material conditions to their limit.

\section{'And now, Rubbish'107}

Children also allow Ramsay to evade the politics of the bin-drivers strike in order to focus on the specific condition of poverty. Ratcatcher resists equally facile 'optimism' and portentous moralism about the life conditions of the working class. Against the slothful 'optimism' of social democracy Benjamin posited the pessimism of surrealism: 'to organise pessimism means nothing other than to expel moral metaphor from politics and to discover in political action a sphere reserved one hundred per cent for images'. ${ }^{108}$ Although scenes were scripted for 'Artie', 'an overly officious shop steward', the film lacks didactic content or metaphorical consolation in the moral rectitude of the proletariat. ${ }^{109}$ Instead, the strike's impact on a working-class community throws-up intra-class divisions. When Artie ('sanctimoniously') yells

\footnotetext{
${ }^{106}$ Watson 1998, p. 68.

${ }^{107}$ Reginald Bosanquet introducing reports of the drivers disputes in Glasgow and Liverpool, News at Ten, ITN, 21 March 1975, in The Glasgow University Media Group 1976, p. 244.

${ }^{108}$ Benjamin 1997, p. 238.
} 
'fuckin' scabs' at strike-breaking troops his appeal for solidarity receives only derisory comments from the women leaning out of nearby windows. Neither does the mysterious adult world of work come into the purview of children. Only the accoutrements of waged labour are visible to children as adults return from and leave for work, such as the industrial paint James's Da brings home to decorate the house (colour - battleship grey) and Ma's work overalls.

Ratcatcher's child-centred focalisation thus adopts an orthodox art cinema stratagem for transforming the concreteness of class struggle into a backdrop for universally applicable humanist themes. As Ramsay said, 'It has been put to me that the politics of the strike are not dealt with in the film, but a boy like James would hardly be concerned with politics, would he?'. ${ }^{110}$ Yet the strike cannot be dodged quite so easily. Strikes are a momentary revolt against the terms of the labour contract, the root of endemic alienation. The appearance on Glasgow's streets and backyards of uncollected rubbish cannot simply serve as a metaphorical or mystical playground without acknowledging its place as a concrete site of bitter class struggle. Specifically, HGV drivers, including dustcart drivers, employed by Glasgow Corporation struck in autumn 1974 for parity with the minimum wage awarded to private sector HGV drivers. Work resumed after four weeks on the understanding that if national negotiations failed to produce parity then the Corporation would negotiate a local agreement. When this failed to happen Glasgow drivers struck for the second time in three months in January 1975. However 'bloody-minded' or unreasonable the HGV drivers' strikes of 1974 and 1975 appear on the surface they demand that a standpoint be taken. At the time the media and the state adopted an ideological

\footnotetext{
${ }^{109}$ Ramsay 1999, p. 11.
} 
standpoint consistent with their class interests. The Glasgow drivers strike became the occasion for the first use of troops in an industrial dispute in twenty-five years. The Glasgow University Media Group argued that television news coverage of the three month-long 'Glasgow rubbish strike' of 1975 adopted an unremittingly negative and hostile standpoint, concentrating on the threatened 'health hazard', while unofficial strikers were too weakly positioned in the 'hierarchy of access' to impress their own definition of the dispute onto audience consciousness. None of the strikers were interviewed for national television reports during the entire period of the strike. And neither would viewers have much sense that the unofficial strikers were also in conflict with their own union, the TGWU, whose officials were interviewed as the legitimate representatives of the strikers. Television audiences had little knowledge of neither the immediate cause of the strike nor the just conviction of strikers like Tom Docherty, interviewed by ITN News on his return to work,

Tom Docherty: I would go on strike for the same cause again because we're qualified drivers ...

Reporter: $\quad$ But going on strike doesn't appear to have achieved anything because the army can come in and do your work?

Tom Docherty: Certainly, because we didn't have union backing this time.

Reporter: $\quad$ So why go on strike again?

Tom Docherty: We'll go on strike on principle and we're entitled to this money. And there's nobody saying we won't go on strike. We definitely

${ }^{110}$ Francke, 1999, p. viii. 
will. If it comes to the cause again, and it's a justful cause, we must go on strike for it again. ${ }^{111}$

As the Glasgow University Media Group argue, the atomised television viewer is encouraged by omission and selection in the dominant framing of how strikes are reported to attribute "their cause to the unreasonable because unexplained action of labour'. ${ }^{112}$ Criticisms that the Glasgow University Media Group's analysis concentrated too narrowly and selectively on the point-of-view of the strikers and failed to reckon sufficiently with the day-to-day pragmatism of news reporters somewhat misses the point that the strikers viewpoint is rarely reported with any conviction. ${ }^{113}$ More than that, the fabled 'neutral, objective' point of view of journalistic professionalism, where officially-approved non-striking professionals discourse with authority about striking non-professionals, veils a partial perspective situated within a field of contending class forces.

\section{Happiness and horror}

A further thematic difficulty in Ratcatcher is the representation of children as moral innocents, 'like a blank canvas' (Ramsay) lacking the baggage of second nature habituation. Benjamin, like Vygotsky, entertains no idealized version of childhood:

The fact is that the perceptual world of the child is influenced at every point by traces of the older generation, and has to take issue with them. The same applies to

\footnotetext{
111 The Glasgow University Media Group 1976, p. 256..

112 The Glasgow University Media Group 1980, p. xiv.

${ }^{113}$ See Harrison 1985.
} 
the child's play activities. It is impossible to construct them as dwelling in a fantasy realm, a fairy-tale land of pure childhood or pure art. ${ }^{114}$

Every childhood achieves something great and irreplaceable for humanity. By the interest it takes in technological phenomena, by the curiosity it displays before any invention or machinery, every childhood binds the accomplishments of technology to the old worlds of symbol. There is nothing in the realm of nature that would be exempt from such a bond. Only, it takes form not in the aura of novelty but in the aura of the habitual. ${ }^{115}$

In practice, Ratcatcher's standpoint is not wholly devoid of the resistant material of childhood or the traces of adulthood. Ratcatcher's dialectical optic recovers repressed inner traces of horror and happiness as mediated by childhood play before they become frozen together in the adult world of alienation and reification. Play helps transform 'a shattering experience into habit'; repetition turns play into an alien, grotesque form.

Habit enters life as a game, and in habit, even its most sclerotic forms, an element of play survives to the end. Habits are the forms of our first happiness and our first horror congealed and become deformed to the point of being unrecognizable'. ${ }^{116}$

The dustcart drivers' strike provides the setting for recalling first happiness and first horror. Ramsay remembered the strike as something that brought her brutal-beautiful notion of the urban together in something like a pre-modern carnivalesque: 'It felt

\footnotetext{
${ }^{114}$ Benjamin 1928, p. 118.
} 
quite medieval, a lot of fun. I was always fascinated by things that are ugly-beautiful, like the canal'. ${ }^{117}$

From a kid's point of view this kind of realism gave me a licence to go from brutality to beauty. It lends itself to the psychology of the character's world, how it is to see the unthinking brutality of kids and, still, how you kind find a certain kind of beauty in this. ${ }^{118}$

Stuck between brutality and beauty Ratcatcher's children are subject to an arbitrary selection, a kind of environmental destiny determined by the local canal. 'The environment is an enormous determining metaphor for James and Kenny. Their environment is very important'. ${ }^{119}$ Charles Taylor sees the garbage-lined landscape as a rather obvious metaphor for 'the emotional pestilence breeding among the inhabitants of this no-hope slum'. ${ }^{120}$ Early on, eleven-year-old Ryan is accidentally drowned in the canal. 'Drowning becomes a motif, whether it be in muddy waters or garbage or drink or the inability to control events or, in the film's most beautiful image, in a cornfield seen through a window'. ${ }^{121}$ The local gang 'playfully' threaten to throw James into the canal. James eventually appears to drown himself near the film's end. For ten year-old Kenny the canal is a source of fascination, especially after James tells him about the exotic fish that swim there. James's despondency is heightened when Kenny is nearly drowned while fishing in the canal, saved only by James's father. Death and near-death experiences are not to be read literally. For

\footnotetext{
${ }^{115}$ Benjamin 1999c, p. 461.

${ }^{116}$ Benjamin 1928, p. 120

${ }^{117}$ Quoted in Romney, 1999

${ }_{118}$ Author interview with Lynne Ramsay, 6 May 2000.

${ }^{119}$ Author interview with Lynne Ramsay, 6 May 2000.

${ }^{120}$ Taylor 2000.
} 
Ramsay, 'it's more about the death of childhood. In the end perhaps it's a metaphorical death - the death of James's spirit' ${ }^{122}$ Ratcatcher's over-indulgence in the pictorial as metaphor - for death, psychology, environment - is the obverse of its refusal to deal categorically with the class politics at stake.

Between danger and experimental play stands an ambiguous relationship to space, where the boundaries between casual violence, accident and rough play are blurred. Margaret Anne is regularly abused by the local gang of boys, yet she seems to be quietly consigned to her fate. As Ramsay said, 'She's awkward but flirtatious; there's something in her eyes that puts her above everything, ${ }^{123}$ She doesn't hide the price of co-occupying the gang's spaces, whether outside near the canal where her grazed knee provides a badge of her defiant pain, or indoors, complying with the gang's sex ritual. After being abused, James rests on her body, vainly trying to conceal it from the gang's merciless gaze. When James runs away from home to Margaret Anne's flat they share a playful bath, cleansing each other's bodies and pain. Emotionally soothed and physically cleansed Margaret Anne sits on the toilet and unselfconsciously urinates in front of an astonished James. In this scene, the earlier shots of her grazed knee, her (willing?) participation in gang sex and her careless bodily exposure, which James awkwardly tries to shield from the gang, Margaret Anne's adolescent body passively absorbs physical contact as part of the process of becoming numb, an indifferent shock absorber fully prepared for a hostile world.

For Ramsay, the rubbish littering the streets and back courtyards of the houses acts as a metaphor for the psychological confusion that James is going through. He feels guilt

${ }^{121}$ Gilbert 2001. 
at his involvement in the accidental drowning of his friend, Ryan. James' melancholic behaviour can also be read in terms of the Oedipal dynamics of the protective maternal authority of his Ma, Anne Gillespie, and the hostile paternal authority of his Da, George Gillespie. When council officials turn-up to assess the condition of the house as part of Gillespie family's re-housing application they can only see the surface mess that litters the house and a dishevelled, dirty father with a whiff of drink on his breath. In fact, George has been resting after his rescue of Kenny from the canal, accounting for his sorry state. George blames James for letting the council officials into the flat when it was in poor condition and risking their rehousing. However, had he refused to let them in we have the feeling that James would still be blamed.

Public space, especially at night, is made inherently dangerous for and by young men. George's face is slashed by a teenage gang. As the red blood runs down his face the shot cuts to deep red raspberry syrup running from an ice cream through a little girl's fingers. Bleeding badly, on his return home George lashes out at Anne, destroying the family party planned in his honour. Yet, despite the irruptive power of the scene this is not the wife-battering that some critics see. ${ }^{124}$ George and Anne also struggle to protect each other against the brutality of the world. In a long scene held by an unflinching camera, the pair dance inseparably to the popular song, 'Something Stupid'. As Ramsay says, 'I like this dancing scene because we shot it long and it runs for almost the entire song. You're forced to watch the whole thing - they're like statues standing there'. ${ }^{125}$ Such 'breathing space' is made to feel like slow

\footnotetext{
${ }^{122}$ Quoted in Francke 1999, p. x.

${ }^{123}$ Quoted in Spencer 1999, p. 18.

${ }^{124}$ See O'Sullivan 1999.

${ }^{125}$ Quoted in Spencer 1999, p.19.
} 
asphyxiation. While Ratcatcher's adult bodies become living room 'statues' its children's bodies are more fully permeated by the physical fragments of 'surreal disorder' of an urban environment defined by dirty canal water, discarded debris, outside toilets, backyards, street pavements. ${ }^{126}$

\section{Dreaming of suburban and stellar escape}

Unable to discuss his confused feelings James finds temporary escape away from the rubbish-strewn city streets in a semi-rural housing estate under construction.

Compared to the brutal, compressed landscape of rubbish-lined streets, nondescript houses and the treacherous canal, a whole new organisation of space opens-up to James in the suburban housing scheme. Ramsay shows the transition from the urban to the semi-rural by shooting the passing pavement from the top deck of a travelling bus. Here we temporarily glimpse Margaret Anne, the subject of James's melancholic drives, as the camera swivels back in slow motion to follow her as the bus moves forward. The shot returns to the rubbish-lined pavements that the bus passes until, leaving all this behind, green shapes replace grey, brown and black ones. At the end of his journey, James disembarks at a semi-rural housing scheme and explores the bare interior space of an unfinished, skeletal house. This uninhabited, half-finished house is not yet haunted by what Bachelard refers to as the 'group of organic habits' that an 'unforgettable house' engraves on us through temporal repetition and spatial familiarity. This house knows of no 'organic habits' since it is lying in a state of inorganic part-construction, a condition that temporarily liberates James from the repeated blows dealt in his own home. Children, who are not yet reduced to servicing 'organic habits', retain a capacity to actively work on interior spaces and cannot be

${ }^{126}$ Ramsay 1999, p. 95. 
fixed ahistorically, as Bachelard does, to primordial memories of a 'Motionless

Childhhod'. ${ }^{127}$ James' discovery of the house-shell not-yet-filled with fixed parts sets childhood into historical motion to test the unplumbed fittings and dream the fantasy of filling the house with concrete use values. Though none of the bathroom fittings have yet been plumbed-in James urinates into the toilet pan, creating a damp pattern on the concrete floor at the base of the pan, and stretches himself out in the empty bath. perfectly framed interior shot provided by the rectangle of a window space opens-up to James a wondrous view of a golden field. As Ramsay said,

The idea of the new house is built up into something that feels quite unreal. You're not sure whether the family will ever get it, but there's this vague hope. James's first visit to this empty house is also probably the first time he's ever seen a field, so I wanted to give this field a wide-open, almost Midwestern American feel. ${ }^{128}$

This is my favourite scene. When James walks through the wide-open space of the golden field it gives a feeling of walking through space with some sense of mystery attached to that space. The field is not just any old scabby field but James' space. $^{129}$

However, even the exhilarating space of the field is outdone when Kenny magically transports his pet mouse, Snowball, to the moon in a fleeting moment of defiant imaginative escape. In an unexpected juxtaposition of fantasy animation, reminiscent of the 1970s television show The Clangers, tied to a balloon Snowball floats into the

${ }^{127}$ Bachelard 1957, p.14. See the critical discussion of Bachelard's idealist account of the House in Mieville 1998, pp. 10-12.

${ }^{128}$ Quoted in Spencer, 1999, p. 19.

${ }^{129}$ Author interview with Lynne Ramsay, 6 May 2000. 
stratosphere and lands on a mouse-infested moon, a parallel perhaps to the rat-infested city streets. Kenny only 'launches' Snowball to impress the local gang, who have already shown that they can represent sudden danger to smaller children. Ramsay makes it clear that due to compressed living conditions children need a breathing space to escape adult and peer surveillance. Snowball's dreamscape sequence 'allows even the most cruel situation to lead into a childish fantasy - still maintaining an innocence, a breathing space in a relentless environment'. ${ }^{130}$ For Benjamin, such 'breathing space' is a pre-requisite for arriving at bodily innervation, the steadying sensation that things are indeed changeable.

Ramsay does not trade on an easy 'contaminated urban rubbish/pure countryside' distinction. Illusions of James's escape to a semi-urban life are shattered on his last visit to the new housing scheme. 'His' house has been finished and he finds himself locked-out, peering-in through the rain-streaked glass of a newly-fitted window. Our vision of the field becomes more obscure, the momentary clarity of suburban redemption covered-up by yet another layer of rain-soaked reality. Even with the aid of camera optics Ratcatcher's children struggle throughout to retain a field of vision. Vision is blurred for Margaret Anne after the gang throw her glasses into the canal. Later, as gang members take it in turns to have sex with her she is unable to tell them apart. When James' fails to retrieve her glasses from the canal we can see how feeble his efforts are but from the perspective of Margaret Anne's blurred world his lack of success is taken on trust. Margaret Anne repays his bad conscience by telling the gang about James's confession of love for her. James's humiliation leads directly back to

${ }^{130}$ Quoted in Francke, 1999, p. ix. 
the canal where her undisturbed glasses lie. At this spot James drowns himself, the final anaesthetic protection against repeated shocks.

\section{A Benjamin Tableau of Utopian Realism}

Ratcatcher is imprinted with the hallmarks of a Benjamin tableau. Self-alienation is recognisable in both its allegorical and utopian aspects. The utopian 'mystery of the mysterious' resides in filmic images of the everyday that betray their own technological organisation. Ramsay employs her technical apparatus to arrest naturalistic illusion and 'seize hold of a memory as it flashes up at a moment of danger'. ${ }^{131}$ As she put it, 'I've always relished contradiction. Performances, cutting, camerawork. I like them all to work against each other' ${ }^{132}$ Ratcatcher's camerawork tests our visual perception. A dialectical optic of children's play and confinement operates among piles of urban debris, spent exchange values as the price of 'progress' but also a subversive 'chance' for childhood innervation. Melancholia is not denied by the film's utopian aspects but recognised by aligning memory and understanding to seeing. James's melancholic dilemma is visible but simultaneously impenetrable. Possibilities emerge in a new arrangement of domestic space with the discovery of the house-shell only to be thwarted by an unceasing training for future shocks of habituated everyday practice.

Even now, in the age of technological miniaturisation and digitisation, film technic retains the potential to filter moments of recognition from and of anaesthetised selfalienation. Then, the mythical 'hard city' becomes pliable, like Semtex, 'in order to blast a specific era out of the homogenous course of history - blasting a specific life

\footnotetext{
${ }^{131}$ Benjamin 1973a, p. 247.
} 
out of the era or a specific work out of the lifework'. ${ }^{133}$ Cinematically, then, a 'specific work' like Ratcatcher detonates the optical unconscious from the 'lifework' onto the surface of the screen, simultaneously arresting and cancelling the myth of the hard city. That condition, of absorbing the blows dealt by capital's control over the city's commodified spaces of production and consumption, has not been conjured away simply by a marketing alteration of Glasgow from industrial 'Second City of the Empire' to consumer-led 'Post-Industrial Emporium' ${ }^{134}$ The hyper-Taylorism of contemporary call centres which today proliferate around Glasgow's hinterland demand from waged labour an intense emotional performance, the psychic dissonance of combined alertness and numbness, to parry the repetition of shocks in the form of unrelenting telephone calls. ${ }^{135}$ Benjamin reminds us that the 'cultural treasures' of the kind carried aloft in Glasgow's 'urban renewal' owe their existence to 'the anonymous toil' of forgotten masses who live as a rule in a perpetual 'state of emergency'.136

Following the naturalistic depiction of James's death in the canal Ratcatcher ends with magical redemptive imagery. Ramsay scripted the final shots:

\section{EXT. WHEAT FIELD. DAY}

The clouds and blue sky reflect in the surface of Anne Marie's mirror. The surreal procession of furniture bearers continues through the golden wheat field by the river, towards the new houses.

\footnotetext{
${ }^{132}$ Quoted in Spencer 1999, p. 17.

${ }^{133}$ Benjamin1973a, p. 254.

${ }^{134}$ See Mooney and Johnstone 2000.

${ }^{135}$ See Taylor 1998, Taylor and Bain 1998, and Thompson, et al, 2000.
} 


\section{INT./EXT. KITCHEN IN NEW HOUSE LOOKING ON TO FIELD. DAY}

The procession of furniture bearers moves closer.

\section{EXT. SUMMERSTON FIELD. DAY}

A way behind walks James, a chair carried high on his shoulders. ${ }^{137}$

As if in answer to Benjamin's demand that 'only the historian will have the gift of fanning the spark of hope in the past who is firmly convinced that even the dead will not be safe from the enemy if he wins', with James's resurrection Ramsay wrests the tradition of social realism's closed ending away from the overpowering force of naturalistic conformism. ${ }^{138}$ This 'surreal procession' represents a remarkable reversal of the 'triumphal procession' depicted by Benjamin 'in which the present rulers step over those who are lying prostrate'. ${ }^{139}$ In the Gillespie family procession only the most banal household objects are carried aloft. This is not the triumphalist denial by the ruling class of 'the anonymous toil of contemporaries' but its fleeting utopian recognition. To reverse a well-known aphorism of Benjamin's, Ratcatcher is a document of barbarism glistening with the civilisation still to come.

\footnotetext{
${ }^{136}$ Benjamin 1973a, p. 248.

${ }^{137}$ Ramsay 1999, 104.

${ }^{138}$ Benjamin 1973a, p. 247.

${ }^{139}$ Benjamin1973a, p. 248.
} 


\section{References}

Adorno, Theodor 1977, 'Commitment', in Aesthetics and Politics, Ernest Bloch, Georg Lukacs, Bertolt Brecht, Walter Benjamin and Theodor Adorno, London: NLB.

Adorno, Theodor W. 1984, Aesthetic Theory, London: Routledge \& Kegan Paul.

Bachelard, Gaston 1957 [1964], The Poetics of Space, Boston: Beacon Press.

Benjamin, Walter 1928, 'Toys and Play', in Walter Benjamin 1999a.

Benjamin, Walter 1929a, 'Chaplin in Retrospect', in Walter Benjamin 1999a.

Benjamin, Walter 1929b, 'Program for a Proletarian Children's Theater', in Walter Benjamin 1999a.

Benjamin, Walter 1931, 'Left-wing melancholy', in Walter Benjamin 1999a.

Benjamin, Walter 1932, 'Ibizian Sequence', in Walter Benjamin 1999a.

Benjamin, Walter 1933a, 'On the Mimetic Faculty', in Walter Benjamin 1999a.

Benjamin, Walter 1933b, 'Doctrine of the Similar', in Walter Benjamin 1999a.

Benjamin, Walter 1973a, 'Theses on the philosophy of history', in Illuminations, London: Fontana Press.

Benjamin, Walter 1973b, 'The work of art in the age of mechanical reproduction', in Illuminations, London: Fontana Press.

Benjamin, Walter 1973c, 'On some motifs in Baudelaire', in Illuminations, London: Fontana Press.

Benjamin, Walter 1973d, 'The image of Proust', in Illuminations, London: Fontana Press.

Benjamin, Walter 1973e, Charles Baudelaire: A Lyric Poet in the Era of High Capitalism, London: Verso Classics.

Benjamin, Walter 1977, 'The author as producer', in Understanding Brecht, London: Verso.

Benjamin, Walter 1997, One-Way Street and Other Writings, London: Verso.

Benjamin, Walter 1999a, Selected Writings: Volume 2, 1927-1934,

Cambridge, Massachusetts: The Belknap Press of Harvard University

Press. 
Benjamin, Walter 1999b, 'K [Dream City and Dream House, Dreams of the Future, Anthropological Nihilism, Jung]', in The Arcades Project, Cambridge, Massachusetts: The Belknap Press of Harvard University Press.

Benjamin, Walter 1999c, 'N [On the Theory of Knowledge, Theory of Progress]', in The Arcades Project, Cambridge, Massachusetts: The Belknap Press of Harvard University Press.

Benjamin, Walter 1999d, 'X [Marx]', in The Arcades Project, Cambridge, Massachusetts: The Belknap Press of Harvard University Press.

Benjamin, Walter and Adorno, Theodor Wiesengrund 1999, The Complete Correspondence, 1928-1940, Cambridge: Polity Press.

Bradley, Lloyd 2000, Bass Culture; When Reggae was King, London: Viking.

Bratu Hansen, Miriam 1999, 'Benjamin and Cinema: Not a One-Way Street', Critical Inquiry, 25, Winter: 306-43.

Buck-Morss, Susan 1989, The Dialectics of Seeing: Walter Benjamin and the Arcades Project, Cambridge, Mass.: MIT Press.

Buck-Morss, Susan 1992, 'Aesthetics and anaesthetics: Walter Benjamin's Artwork essay reconsidered', October, 62, Fall: 3-41.

Burger, Peter 1984, Theory of the Avant-Garde, Manchester: Manchester University Press.

Damer, Sean 1989, From Moorepark to 'Wine Alley': TheRise and Fall of a Glasgow Housing Scheme, Edinburgh: Edinburgh University Press.

Donald, James 1999, Imagining the Modern City, London: The Athlone Press.

Francke, Lisa 1999, 'Childhood is a blank canvas: Lynne Ramsay interviewed', in Ramsay.

Frisby, David 1985, Fragments of Modernity: Theories of Modernity in the Work of Simmel, Kracauer and Benjamin, Cambridge: Polity Press.

Gilbert, W. Stephen 2001, 'Ratcatcher', Film Journal International, http://www.filmjournal.com/Article.cfm/PageID/42334732.

Giliken, Alex 2001, 'Realisms and byond in Lynne Ramsay's Ratcatcher', Media Education Journal, 31: 14-17. 
Gilloch, Graeme 1996, Myth and Metropolis: Walter Benjamin and the City, Cambridge: Polity Press.

The Glasgow University Media Group 1976, Bad News, London: Routledge \& Kegan Paul.

The Glasgow University Media Group 1980, More Bad News, London:

Routledge \& Kegan Paul.

Hansen, Miriam 1987, 'Benjamin, cinema and experience: the blue flower in the land of technology', New German Critique, 40, Winter: 179-244.

Hansen, Miriam 1993, 'Of mice and ducks: Benjamin and Adorno on Disney', South Atlantic Quarterly, 92, Winter: 27-61.

Harrison, Martin 1985, TV News: Whose Bias?, London: Policy Journals.

Hill, John 1986, Sex Class and Realism British Cinema 1956-1963, London: British Film Institute.

Hill, John 2000, 'Failure and Utopianism: Representations of the Working Class in British Cinema of the 1990s', in British Cinema of the 1990s, edited by R. Murphy, London: British Film Institute.

Jameson, Frederick 1977, 'Reflections in conclusion', in Aesthetics and Politics, Ernest Bloch, Georg Lukacs, Bertolt Brecht, Walter Benjamin and Theodor Adorno, London: NLB.

Jennings, Michael 1987, Dialectical Images: Walter Benjamin's Theory of Literary Criticism, Ithaca, NY: Cornell University Press.

Kracauer, Siegfried 1947, From Caligari to Hitler: A Psychological History of German Film, Princeton: Princeton University Press.

Leck, Ralph M 2000, Georg Simmel and Avant-Garde Sociology: The Birth of Modernity, 1880-1920, New York: Humanity Books.

Leslie, Esther 2000, Walter Benjamin: Overpowering Conformism, London: Pluto Press

McKibbin, Tony 2000, 'Retouching the real: Lynne Ramsay's Ratcatcher', Cencrastus, 65.

Matheson, David 2002, 'Limited language in limited minds? Urban Scots as a language of poverty', Marges Linguistiques, 3, Mai: 106-117.

Mieville, China 1998, 'The conspiracy of architecure: Notes on a modern anxiety', Historical Materialism, 2: 1-32. 
Mooney, Gerry and Charlie Johnstone 2000, 'Scotland divided: poverty, inequality and the Scottish Parliament', Critical Social Policy, 20, 2: 155182.

O’Hagan, Sean 1999, 'Running into a bright future', The Observer, 31 October.

Pendreigh, Brain 1999, 'The catcher with an eye', The Guardian, 14 August.

Pensky, Max 1993, Melancholy Dialectics: Walter Benjamin and the Play of Mourning, Amerhurst: University of Massachusetts Press.

Petrie, Duncan 2000, Screening Scotland, London: BFI.

Ramsay, Lynne 1999, Ratcatcher. London: Faber and Faber.

Romney, Jonathan 1999, 'Child play', The Guardian, 5 November.

Rottentomatoes 2000, 'Reviews of Ratcatcher', http://www.rottentomatoes.com/m/Ratcatcher.

Shlovsky, Viktor 1917, 'Art as technique', in Art in Theory, 1900-1990: An Anthology of Changing Ideas, edited by Charles Harrison and Paul Wood, Oxford: Blackwell.

Shklovsky, Viktor 1974, Mayakovsky and his Circle, London: Pluto Press.

Spencer, Lisa 1999, 'Ratcatcher', Sight and Sound, 10.

Stark, Elaine 2000, 'Stark Talk: interview with Lynne Ramsay', Radio Scotland, Broadcast: 2 August.

Taylor, Charles 2000, 'A guttersnipe's Pieta', salon.com, 24 October, http://www.salon.com/ent/movies/review/2000/10/24/ratcatcher/index.htm 1.

Taylor, Steve 1998, 'Emotional labour and the new workplace', in Workplaces of the Future, edited by Paul Thompson and Chris Warhurst, London: Macmillan.

Taylor, Phil and Peter Bain 1998, 'An assembly line in the head: work and employee relations in the call centre', Industrial Relations Journal, 30, 2: 101-17.

Thompson, Paul, Chris Warhurst and George Callaghan 2000, 'Human capital or capitalising on humanity? Knowledge, skills and competencies in interactive service work', in Managing Knowledge: Critical Investigations of Work and Learning, edited by C. Prichard, R. Hull, M. Chumer and H. Willmott London: Macmillan Business.

van der Veer, Rene and Jaan Valisner 1991, Understanding Vygotsky: A Quest for Synthesis, Oxford: Blackwell. 
Volosinov, Valentin N. 1973, Marxism and the Philosophy of Language, Cambridge, Ma.: Harvard University Press.

Vygotsky, Lev S. 1962, Thought and Language, Cambridge, Mass.: MIT Press.

Watson, Ben 1998, Art, Class \& Cleavage: Quantulumcunque Concerning Materialist Esthetix, London: Quartet Books. 